\title{
DOI: 10.1515/orga-2015-0022 \\ Social CRM Adoption and its Impact on Performance Outcomes: a Literature Review
}

\author{
Marjeta Marolt ${ }^{1}$, Andreja Pucihar ${ }^{1}$, Hans-Dieter Zimmermann ${ }^{2}$
}

\begin{abstract}
${ }^{1}$ University of Maribor, Faculty of Organizational Sciences, Kidričeva cesta 55a, 4000 Kranj, Slovenia marjeta.marolt@fov.uni-mb.si, andreja.pucihar@fov.uni-mb.si
\end{abstract}

\begin{abstract}
${ }^{2}$ University of Applied Sciences, FHS St. Gallen, Rosenbergstrasse 59, Postfach, 9001 St.Gallen, Switzerland hansdieter.zimmermann@fhsg.ch
\end{abstract}

\begin{abstract}
Background and Purpose: Social customer relationship management (social CRM) is an emerging concept that integrates traditional CRM and social media in order to provide benefits for organizations and customers. Despite the benefits that social CRM can bring, many organizations are still at the early stage of adoption. To move beyond social marketing and to exploit opportunities offered by sales and customer service, organizations need to be aware of factors that drive social CRM adoption and different implications of social CRM adoption for performance outcomes. This paper aims to provide a review of scholarly literature on social CRM adoption with the focus on factors and performance outcomes.

Design/Methodology/Approach: To provide a comprehensive view of social CRM adoption and its impact on performance outcomes, the publications of interest include scholarly journal papers from information systems and marketing disciplines and conference proceedings. Selected publications were reviewed, and findings classified into three categories: the extent of social CRM adoption, the factors influencing CRM adoption, and the impact of social CRM on performance outcomes.

Results: It appears that several issues regarding social CRM adoption and its implications for performance outcomes as well as the actual use of social media in the context of CRM need additional empirical support.

Conclusion: Our observations have confirmed that many researchers proposed social CRM models based on existing theories and concepts of traditional CRM. Nevertheless, some specifics of social media implications on CRM have been overlooked. The researchers therefore suggest further adjustment/extension of their models.
\end{abstract}

Keywords: social CRM; extent of adoption; factors; performance outcomes

\section{Introduction}

As already observed in the review on customer relationship management (CRM) technology in multichannel environment, written by Awasthi and Sangle (2012), in recent years new channels have emerged and one of the integral needs of CRM is the extension of services to multiple channels. The channels that are currently playing an important role in CRM are social media: customers and potential customers are conversing openly about brands, services or products through it, and the utilization of cus- tomer-preferred channels is becoming a must in order to acquire and retain such customers.

According to Lehmkuhl and Jung (2013), there is no generally accepted definition of social CRM; therefore, people have a different understanding of what it is. The most accepted definition of social CRM was defined by Greenberg $(2009$, p. 34) as "a philosophy and a business strategy, supported by a technology platform, business rules, processes and social characteristics, designed to engage the customer in a collaborative conversation in order to provide mutually beneficial value in a trusted and transparent business environment". According to this definition, 
social CRM is a new approach that integrates traditional customer-facing activities with emergent social media applications to engage customers in collaborative conversations to provide mutually beneficial value (Trainor, 2012). Organizations are now using traditional CRM and associated information systems to manage traditional customer transaction data as well as social media that enable them collaboration and knowledge sharing with prospects and customers.

However, according to Faase, Helms, and Spruit (2011) there are sparse directions on how to integrate social media in CRM. Based on the scholarly and practitioner literature review, it appears that social CRM is not a replacement, but rather an extension of traditional CRM (Askool and Nakata, 2011; Yawised, Marshall, and Stockdale, 2013). By linking social media with existing CRM processes, organizations may potentially improve their performance (Acker, Gröne, Akkad, Pötscher and Yazbek, 2011; Choudhury and Harrigan, 2014; Harrigan, 2011; Leary, 2008; Trainor, Andzulis, Rapp, and Agnihotri, 2014).

Researchers recognize the main benefits of social CRM in building trust, gaining customer insights, establishing customer loyalty, achieving customer retention, involving customers in new product or service development, improving customer lifetime value and company reputation, and lowering the cost of service, to name a few (Acker et al., 2011; Küpper, Lehmkuhl, Wittkuhn, Wieneke and Jung, 2015; Sarner et al., 2011; Sigala, 2011; Trainor et al., 2014; Verhoef, Reinartz, and Krafft, 2010; Woodcock, Green and Starkey, 2011; Yawised et al., 2013).

Besides the plethora of benefits, there are also some challenges that social CRM brings. First, the organization needs to identify their business needs and upon that find the most appropriate technology to support them (Kietzmann, Hermkens, McCarthy \& Silvestre, 2011). The organization also needs to set a proper social CRM strategy as well as to move beyond social marketing and exploit opportunities offered by sales, customer service and digital commerce (Sussin, 2015).

Furthermore, the organization needs to know how to engage in conversation with customers online; ideally the employees should be educated in public relations and customer service (Sigala, 2011). Another issue is a lack of control, because the conversation is carried out via social media which is not a property of the organization, but the property of the social media provider as well as everyone involved in the conversation (Kietzmann et al., 2011). Last but not least, organizations are confronted with a challenge on how to measure the performance (Woodcock et al., 2011).

According to Kiron, Palmer, Nguyen Phillips and Berkman (2013), some organizations still consider social business to be an application or tool. Other organizations strive to develop more mature social business capabilities by focusing on key business challenges. They attempt to integrate social business into strategy and operations, and to use it in daily decision making. However, progress is slow (Kiron et al., 2013). To move beyond the marketing department, organizations need be aware of all the opportunities that social media brings, especially for the sales and customer service departments, where social media have great potential (Kiron et al., 2013). Furthermore, organizations need to be aware of factors and outcomes that the broader exploitation of social media in the context of CRM brings. This will help them overcome the barriers they are facing and help them better understand customers' needs, provide better tailored product and services, improve continuous interaction with customers, etc.

Even though the growing body of research on social CRM has become apparent, there are still areas that require further research that will contribute to the growing knowledge base. In this paper, we aim to provide insights into the latest research done in the field of social CRM adoption. The purpose of this paper is to identify areas of concern regarding social CRM adoption as well as its influence on performance outcomes. The findings will serve as the foundation for further research. The paper is organized as follows. In the next section, we present existing literature reviews on social CRM and clarify the addressed issues. In the third section, we present a methodology on how the papers were selected. In the fourth section, we discuss the findings of the review while in the last section, the conclusion and further research directions are presented.

\section{Previous literature reviews in so- cial CRM}

In this section, the existing literature reviews in the field of social CRM are presented. The overview of social CRM literature review publications is presented in Table 1.

The first review on CRM with a key focus on the multiplicity of the channels that mentioned social CRM was published by Awasthi and Sangle in 2012. The purpose of this paper was to provide insights on the adoption of CRM technology, including the CRM in the context of the multichannel environment, based on literature published between 2006 and 2010. The publications were categorized under four main themes based on the main channel of CRM implementation: CRM, multichannel CRM, eCRM, and mCRM. The authors concluded that the focus on CRM with strategic alignment at various levels was the primary concern. They also argue that the empirical support for the technical and nontechnical issues regarding the CRM in multichannel environments needs to be provided.

The first review that was specifically focused on social CRM was presented in a Malaysian Conference on Information Systems in 2013 by Yawised et al. (2013). This review was focused on the comparison between two types of literature (i.e. scholars' and practitioners') and 
Table 1: Earlier literature reviews

\begin{tabular}{|c|c|c|c|c|c|}
\hline & Year & Authors & Papers & Span & Central theme \\
\hline 1 & 2012 & Awasthi and Sangle & 123 & $2005-2010$ & CRM technology in multichannel environment \\
\hline 2 & 2013 & $\begin{array}{c}\text { Yawised, Marshall, and } \\
\text { Stockdale }\end{array}$ & not specified & not specified & $\begin{array}{c}\text { comparison of scholarly and practitioner } \\
\text { literature on social CRM }\end{array}$ \\
\hline 4 & 2014 & $\begin{array}{c}\text { Lehmkuhl and Jung } \\
\text { Lehmkuhl, Walther and } \\
\text { Wieneke }\end{array}$ & 31 & $2005-2012$ & $\begin{array}{c}\text { organizational approaches to designing social } \\
\text { CRM systems }\end{array}$ \\
\hline
\end{tabular}

the identification of future research agendas. The authors concluded that these two types of literature had both general conceptual similarities and differences. The general agreement between them is that social CRM is an extension of traditional CRM and is aimed at "customer engagement". Regarding the differences, the scholarly literature is focused on the specific issues related to the theoretical concept of social CRM, while the practitioner literature pays more attention to how to respond to new challenges and which new opportunities are offered by the emergence of social CRM.

Another literature review was presented at the $26^{\text {th }}$ Bled eConference by Lehmkuhl and Jung (2013). This study presented a review of the most current scholarly literature to provide a comprehensive overview of the current social CRM knowledge base and provide further research directions. The publications were set into four categories with different emphasis on designing social CRM systems or components thereof, including organizational factors, processes, relationship lifecycle, and social CRM framework. While social CRM is a rather new concept, the authors included all publications until August 2012. They concluded that scholarly publications on social CRM are still limited and suggest that future research should empirically explore factors and outcomes of social CRM adoption.

The last review addressing social CRM is published by Küpper, Jung, Lehmkuhl, Walther and Wieneke (2014). The review is focused on performance measures for social CRM. The publications were discussed under four categories of performance measurement systems: infrastructure, process, customer, and organizational performance. The study concluded with suggestions for further research directions toward a preliminary social CRM performance measurement model development.

It can be observed that none of the literature reviews have a key focus on the factors and outcomes of social CRM adoption. Even though some issues have already been addressed by Lehmkuhl and Jung (2013), whose main theme was focused towards organizational approaches to designing social CRM systems, and by Küpper et al. (2014), whose main theme was focused on performance measures for social CRM, they did not provide a holistic view of the factors and outcomes of social CRM adoption. Additionally, due to the appearance of new papers in recent years, there is a paucity of literature reviews on the developments occurring in recent years. To fill these gaps, this paper reviews literature in social CRM with a particular emphasis on the factors and outcomes of social CRM adoption.

\section{Research methodology}

In this section, the review scope and selection of papers are presented. Since social CRM is an interdisciplinary topic, relevant articles are published across different disciplines. Furthermore, while social CRM is a relatively new phenomenon, most of the contemporary research is published in conference proceedings. Therefore, publications of interest include scholarly journal papers from information systems and marketing disciplines as well as conference proceedings from the abovementioned disciplines. To provide a comprehensive bibliography of the academic literature on social CRM, the following available online journal databases were searched: EBSCOhost, ProQuest, Web of Science and Scopus. To ensure the quality of the conference papers we focused only on a few well established (traditional) conferences in the fields of information systems (International Conference on Information Systems (ICIS), European Conference on Information Systems (ECIS), Americas Conference on Information Systems (AMCIS), Hawaii International Conference on System Science (HICSS) and Bled eConference), and marketing (American Marketing Association (AMA) and European Marketing Academy (EMAC)). Those conferences were chosen because they were also selected in several other literature reviews on CRM (e.g. Awasthi \& Sangle, 2012; Küpper, Jung, Lehmkuhl, Walther and Wieneke, 2014b; Paulissen, Milis, Brengman, Fjermestad and Romano, Jr., 2007). Furthermore, Awasthi \& Sangle (2012) observed that among the leading conferences that published papers 


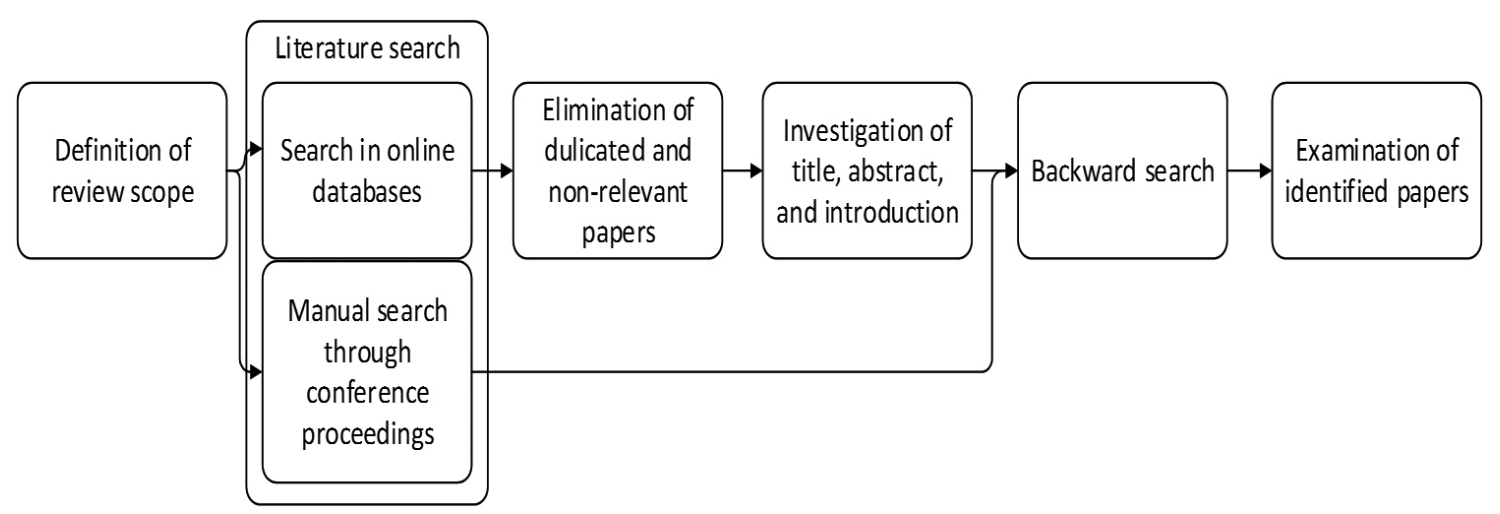

Figure 1: Research approach

Table 2: Results of the qualitatively assessed identified papers

\begin{tabular}{|c|c|c|c|c|}
\hline \multirow{3}{*}{ Database } & \multicolumn{3}{|c|}{ Keyword search } & \multirow{3}{*}{$\begin{array}{c}\text { Backward search } \\
\begin{array}{c}\text { Total evaluated } \\
\text { publications }\end{array}\end{array}$} \\
\hline & \multicolumn{2}{|c|}{ Keywords } & \multirow{2}{*}{$\begin{array}{l}\text { Total evaluated } \\
\text { publications }\end{array}$} & \\
\hline & (a) & (b) & & \\
\hline EBSCOhost & $3(27)$ & $5(53)$ & 8 & \multirow{5}{*}{-} \\
\hline ProQuest & $6(257)$ & $1(367)$ & 7 & \\
\hline Web of Science & $1(2)$ & $2(9)$ & 3 & \\
\hline Scopus & $\mathbf{0}(18)$ & $\mathbf{0}(28)$ & $\mathbf{0}$ & \\
\hline Conferences & \multicolumn{2}{|c|}{-} & 4 & \\
\hline Sum & \multicolumn{2}{|c|}{-} & 22 & 9 \\
\hline \multicolumn{3}{|c|}{ Total net hits } & \multicolumn{2}{|c|}{31} \\
\hline
\end{tabular}

in more than one category (CRM, eCRM, mCRM and multichannel CRM) are HICSS and Bled eConference. Figure 1 presents the research approach.

In this literature review, we focused on the research outcomes and theories applied in the analyzed papers. The goal was to summarize and identify central issues, in an attempt to provide a neutral perspective that involves exposing many sides to an issue. The findings and conclusions of the review are conceptually arranged, which means that results with similar concepts were grouped together (Cooper, 1988).

The considered time span of published publications was 2010 to 2015 due to the recent popularity of the topic in academia and practice. The initial keyword search for papers was performed in June 2015. Due to the focus on the entire chain of social CRM adoption constituted by adoption factors, the extent of adoption and performance outcomes, we searched for papers containing the following keywords:

- (a) "Social CRM" or "SCRM" or "CRM 2.0" or "social customer relationship management" or ("social media" and "CRM") or ("social media" and "cus- tomer relationship management") or ("web 2.0" and "CRM") or ("web 2.0" and "customer relationship management") and "adoption".

- (b) Social CRM" or "SCRM" or "CRM 2.0" or "social customer relationship management" or ("social media" and "CRM") or ("social media" and "customer relationship management") or ("web 2.0" and "CRM") or ("web 2.0" and "customer relationship management") and "performance".

The search results are summarized in Table 2. The number in brackets represents the number of articles found in the respective database using the specific search keyword. Then duplicated entries from the obtained lists were removed and non-relevant papers eliminated from any further investigation. The articles were further evaluated by reading the title, abstract, and introduction. The numbers marked in bold represent the number of articles that were identified relevant to our investigate topic. While some proceedings of the aforementioned conferences are not indexed in the journal databases (for instance, the Bled eConference proceeding for 2014 are still in the process 
of being indexed), we also searched through conference proceeding manually. The manual search identified four additional relevant papers. We also reviewed other work of the authors from the obtained list of relevant papers as well as citations of the papers (Levy \& Ellis, 2006). This so-called backward search yields nine additional relevant papers. The remaining 31 articles were further examined to determine the main findings and identify further research directions.

\section{Findings from literature review}

In this study CRM is defined as an integrated approach that seeks to understand the customer, and the focus is on customer relationship development and customer retention (Chen \& Popovich, 2003). CRM is a complex strategy rather than merely an integration of new information technology (Piskar \& Faganel, 2009).

Drawing on the observation from Damanpour and Schneider (2008) that innovation is not truly adopted until "it has actually been put into use in the adopting organization" (p. 497), this study understands social CRM adoption as the actual use of social media in the context of CRM.

This was also taken into consideration during the process of the literature review. The review points out that emphasis is placed on the issues regarding the theoretical concept of social CRM, usually building a framework or a model on what has already been discovered in prior research. Researchers link their conceptual models with existing theories, such as the Technology Acceptance Model (TAM) (Askool \& Nakata, 2011), the Technology-Organization-Environment Framework (TOE) (Askool \& Nakata, 2012), the Resource-Based View (RBV) and the Dynamic Capabilities Theory, which is the extension of RBV and usually used together with it (Trainor et al., 2014).

As already mentioned, this study focuses on the entire chain of social CRM adoption constituted by adoption factors, the extent of adoption, and performance outcomes. We will start with the findings in regards to the extent of adoption (adoption intensity) and continue with the adoption factors and performance outcomes.

\subsection{Extent of social CRM adoption}

While social media adds another layer of complexity to CRM practice (Verhoef et al., 2010)customer management $(\mathrm{CM}$, researchers are recognizing that directing their research simply on a binary measure (adopt or not adopt) is inadequate. Therefore, they are exploring how to measure the extent of social CRM adoption or in, other words, the actual use of social CRM. Many of them are relying on prior research, especially those studies that focus on CRM capabilities and CRM processes (e.g. information relational processes, customer-facing processes), and adding the specifics of social media (e.g. customer engagement). The review of the existing literature points out that many researchers built their conceptual understandings of social CRM on the RBV theory in combination with the dynamic capabilities perspective or the equity theory (Choudhury \& Harrigan, 2014; Harrigan, Soutar, Choudhury and Lowe, 2015; Trainor et al., 2014; Trainor, 2012).

For instance, the paper from Trainor (2012) presents a conceptual framework that extends a traditional CRM with the integration of social media technologies and suggests how this integration can influence organizational performance. Trainor et al. (2014) tried to follow the challenges identified by Trainor (2012). This paper provides conceptualization and measurement of social CRM capabilities.

A slightly different approach to the social CRM model is presented by Choudhury and Harrigan (2014) and Harrigan et al. (2015). The paper of Choudhury and Harrigan (2014) builds on a previous CRM model proposed by Jayachandran, Sharma, Kaufman, and Raman (2005), adopting RBV theory and the equity theory. They adopted the constructs from previous studies on CRM and included a new construct of customer engagement initiatives that indicate how business and customers interact through social media technologies. Harrigan et al. (2015) followed the study from Choudhury and Harrigan (2014). The changes in the previously mentioned model were made according to the findings. However, not all links proposed in the model were supported.

Furthermore, Rodriguez, Ajjan and Peterson (2014) argue that the effective utilization of CRM and social media starts with understanding customer processes. CRM processes at the customer-facing level are usually defined as a systematic process to manage customer relationships as they move from relationship building to relationship termination (Reinartz, Krafft and Hoyer, 2004).

Sigala (2011) exploited social CRM practices during the lifecycle phases (acquisition, retention, expansion, and win back). Malthouse, Haenlein, Skiera, Wege and Zhang (2013), in contrast, introduced framework, called the "social CRM house", discussing not only how social media engagement affects acquisition, retention, and termination (differentiating high and low customer engagement) but also supporting business areas (i.e. people, IT, performance evaluation, metrics, and strategy). Creating deep connections with customers throughout the customer engagement cycle (i.e. connection, interaction, satisfaction, retention, commitment, advocacy, engagement) introduced by Sashi (2012) is a new approach that is perceived as being relevant for social CRM. The findings of the identified papers are summarized in Table 3. 
Table 3: Summarized finding of the extent of social CRM

\begin{tabular}{|c|c|}
\hline Author & Findings \\
\hline $\begin{array}{l}\text { (Sigala, } \\
2011)\end{array}$ & $\begin{array}{l}\text { Exploitation of Social CRM practices through customer life cycle phases (acquisition, retention, } \\
\text { expansion, win back) seems to be a good approach. Still, in order to verify and enrich the study's } \\
\text { framework, a large and more diversified sample should be used. }\end{array}$ \\
\hline $\begin{array}{l}\text { (Sashi, } \\
2012)\end{array}$ & $\begin{array}{l}\text { Deep connections with customers can be created through the customer engagement cycle } \\
\text { (connection, interaction, satisfaction, retention, commitment, advocacy, engagement). While this } \\
\text { is the first attempt to identify the stages of the customer engagement cycle, further research to } \\
\text { better understand each lifecycle stage is needed. }\end{array}$ \\
\hline $\begin{array}{l}\text { (Trainor, } \\
\text { 2012) }\end{array}$ & $\begin{array}{l}\text { CRM-related capabilities can be developed through the deployment of IT and complementary } \\
\text { resources: relational information processing, customer linking and marketing sensing, } \\
\text { collaborative service and support, social selling and social support. This conceptual model can } \\
\text { serve as a starting point for further research in this area. }\end{array}$ \\
\hline $\begin{array}{l}\text { (Malthouse et al., } \\
\text { 2013) }\end{array}$ & $\begin{array}{l}\text { Social media engagement can be measured through customer lifecycle phases (acquisition, } \\
\text { retention, termination). }\end{array}$ \\
\hline $\begin{array}{l}\text { (Trainor et al., } \\
\text { 2014) }\end{array}$ & $\begin{array}{l}\text { For the social CRM capability the organization-wide system for acquiring, disseminating and } \\
\text { responding to customer information proposed by Srinivasan \& Moorman (2005) is adopted. } \\
\text { While the adopted construct does not include all the important specifics of social media, a measure } \\
\text { that will cover this anomaly should be added. Furthermore, differences between B2B and B2C } \\
\text { businesses should be taken into account. }\end{array}$ \\
\hline $\begin{array}{l}\text { (Choudhury \& } \\
\text { Harrigan, 2014) }\end{array}$ & $\begin{array}{l}\text { The combination of the adopted construct of relational information processes proposed by } \\
\text { Jayachandran et al. (2005) and a new construct of customer engagement initiatives provides } \\
\text { additional insights on how business and customers interact through social media. While it was } \\
\text { observed that the customer engagement initiatives do not influence performance, but relational } \\
\text { information processes do, the interrelationships between customer engagement and relational } \\
\text { information processes should be investigated. }\end{array}$ \\
\hline $\begin{array}{l}\text { (Rodriguez et al., } \\
\text { 2014) }\end{array}$ & $\begin{array}{l}\text { The real value of customer-oriented technologies lies in the way customer orientation processes } \\
\text { use the information provided by the platforms (such as CRM and social media) to enhance the } \\
\text { customer's experience. }\end{array}$ \\
\hline $\begin{array}{l}\text { (Harrigan et al., } \\
\text { 2015) }\end{array}$ & $\begin{array}{l}\text { The construct proposed by Choudhury and Harrigan (2014) was slightly changed. Surprisingly } \\
\text { this study revealed that there is no direct link between relational information processes and } \\
\text { customer relationship performance. Therefore, further investigation of the relational information } \\
\text { processes construct is needed. }\end{array}$ \\
\hline
\end{tabular}

Overall, several studies attempted to capture the extent of social CRM adoption within organizations. Based on the findings, we can conclude that the adopted constructs from previous CRM studies still need improvements. This means that more specifics of social media should be added to existing measurement approaches and some existing measures accordingly reformulated. Additionally, more em- phasis should be given towards the empirical investigation of the proposed concepts. 


\subsection{Factors influencing social CRM adop- tion}

To identify factors that influence social CRM adoption, some researchers linked their models with the existing theories, including TAM (Askool \& Nakata, 2011), TOE (Askool \& Nakata, 2012) and the Dynamic Capabilities theory (Harrigan \& Miles, 2014). Askool and Nakata (2011) used TAM as a starting point for building their conceptual model, identifying customers as well as organizational factors that influence social CRM adoption. In 2012 they conducted new research in which they studied enterprise social CRM adoption (Askool \& Nakata, 2012).

They used the TOE framework to predict organizations' adoption intention. They used semi-structured interviews and identified several differences between the results of the study and other literature in the field of information systems (i.e. technological and knowledgeable IT staff are not core factors of social CRM adoption; customers were not considered to be the main driver to adopt social CRM).

They propose that further research should extend the model with other factors (i.e. relative advantage, complexity, compatibility, top management support, inter-organizational networks, organizational innovativeness), followed by in-depth analysis of social CRM influence on both customer and organizations. Harrigan and Miles (2014) used the Dynamic capabilities theory in order to investigate factors that influence social CRM activities of SMEs. They found that online communities are presenting the biggest shift from eCRM to social CRM. This factor describes how the importance of customer engagement in online communities drives SMEs to manage and use online communities in CRM.

There are also some studies in which researchers did not provide a direct link to the existing theories. Woodcock et al. (2011) for instance present a checklist that can be helpful for organizations that are planning to integrate social CRM with their existing way of how they mana-

Table 4: The factors considered in previous studies

\begin{tabular}{|c|c|c|}
\hline Factors & Authors & Description \\
\hline $\begin{array}{l}\text { Information technology } \\
\quad \text { infrastructure }\end{array}$ & $\begin{array}{l}\text { (Malthouse et al., 2013; } \\
\text { Woodcock et al., 2011) }\end{array}$ & $\begin{array}{l}\text { IT architecture seems to be crucial because SM tools } \\
\text { need to be integrated with traditional CRM systems in } \\
\text { order to obtain a full picture of customer's behavior. }\end{array}$ \\
\hline Employee skills & $\begin{array}{l}\text { (Askool \& Nakata, 2012; } \\
\text { Malthouse et al., 2013; } \\
\text { Sigala, 2011; Woodcock et } \\
\quad \text { al., 2011) }\end{array}$ & $\begin{array}{l}\text { Availability of sufficiently skilled experts proves to be a } \\
\text { major challenge towards adoption. }\end{array}$ \\
\hline Organizational culture & $\begin{array}{l}\text { (Harrigan \& Miles, 2014; } \\
\text { Malthouse et al., 2013; } \\
\text { Woodcock et al., 2011) }\end{array}$ & $\begin{array}{l}\text { A company culture needs to encourage employees to } \\
\text { actively participate and engage in social media that can } \\
\text { influence adoption. }\end{array}$ \\
\hline Perceived benefits & $\begin{array}{l}\text { (Askool \& Nakata, 2012; } \\
\text { Malthouse et al., 2013; } \\
\text { Sigala, 2011; Woodcock et } \\
\text { al., 2011) }\end{array}$ & $\begin{array}{c}\text { The appropriate metrics for measuring and managing } \\
\text { the social value of customers influence the perception } \\
\text { of the perceived benefits and consequently influence on } \\
\text { adoption. }\end{array}$ \\
\hline Management support & $\begin{array}{l}\text { (Askool \& Nakata, 2012; } \\
\text { Woodcock et al., 2011) }\end{array}$ & $\begin{array}{l}\text { The top management encouragement towards the use } \\
\text { of social media seems to have a great influence the } \\
\text { adoption. }\end{array}$ \\
\hline Social CRM strategy & $\begin{array}{l}\text { (Malthouse et al., 2013; } \\
\text { Sigala, 2011; Woodcock et } \\
\text { al., 2011) }\end{array}$ & $\begin{array}{l}\text { An organization should determine its social CRM } \\
\text { strategy according to the level of customer engagement. } \\
\text { This includes evolving social CRM policies and } \\
\text { guidelines that can influence adoption. }\end{array}$ \\
\hline
\end{tabular}


ge customers' relationship. The management support has been identified as a very important along with building and retaining the skilled employees in this area, evolving working culture, evolving social CRM policies and guidelines, changing the nature of measurement and evaluation and development of right IT and data architecture. A similar set of factors was also identified by Sigala (2011) and Malthouse et al. (2013). Table 4 presents factors that several researchers considered as important when adopting social CRM.

As already mentioned, the researchers used quite a few factors that had been already identified as important in previous studies on CRM adoption. Fewer studies identified new factors that are perceive relevant only for the social CRM adoption (e.g. social CRM strategy, online communities). We can conclude that the factors that have proven to have an impact on the adoption of CRM are also considered important in the context of social CRM adoption. Because the above-mentioned studies are mainly of a conceptual nature or the results are based on interviews the importance or relevance of factors should be verified on a larger sample. Additionally more emphasis should be given to how these factors influence the extent of social CRM adoption.

\subsection{Impacts of social CRM adoption on performance outcomes}

As already noted in the extent of social CRM adoption section some researchers linked social CRM with performance outcomes to provide evidences on how social CRM can deliver benefits for organizations as well as for customers (Baird \& Parasnis, 2011; Choudhury \& Harrigan, 2014; Harrigan et al., 2015; Rodriguez et al., 2014; Trainor et al., 2014; Trainor, 2012; Woodcock et al., 2011).

Furthermore, researchers also argue that there is a need to identify appropriate performance outcomes for social CRM (e.g. Harrigan et al., 2015; Michaelidou, Siamagka and Christodoulides, 2011; Sigala, 2011).

Greenberg, the author of the most frequently cited social CRM definition, was also one of the first who posit the question regarding how to measure social CRM performance outcomes. In his paper Greenberg, 2010), he discussed how the nature of consumers' web activity is changing organizations' performance measurement approaches. He notices that the influence of social CRM on performance outcomes cannot be measured merely by traditional quantitative measures, but it also requires new measures that "can be used to measure the emotional tone and influence of the conversations in the ether that are going on outside the corporate firewalls" (Greenberg, 2010, p. 417).

According to Verhoef, Reinartz and Krafft (2010) there are several performance outcomes of traditional CRM, including customer retention, customer lifetime value/customer equity and new product performance that can also be related to social CRM. Furthermore Sigala (2011), who studied the usage and readiness of Greek tourism organizations for social CRM, proposed further research that will assess the effectiveness of social CRM practices. The author suggests examining the impact of social CRM practices on performance outcomes, including customer loyalty, customer profitability and sales data, quality levels, and company reputation. Similarly Malthouse et al. (2013) suggested performance evaluation and providing guidelines for developing KPIs to measure the performance of each component of the framework they proposed (CRM house) including performance outcomes.

Studies that used the RBV theory in combination with the dynamic capabilities perspective or the equity theory made some progress and empirically tested the impact of social CRM on customer relationship performance.

While Trainor et al. (2014) found that social CRM capabilities have a positive influence on customer relationship performance (customer satisfaction and customer loyalty), Choudhury and Harrigan (2014) did not support the link between customer engagement initiatives and customer relationship performance (environmental dynamism and competitive intensity).

However, they found a link between relational information processes and customer relationship performance. Therefore, their study illustrates the fact that social CRM through a range of processes and relationships can improve customer relationship performance. Surprisingly, Harrigan et al. (2015) did not support the link between relational information processes and customer relationship performance (customer satisfaction and customer loyalty). These authors emphasized doubts about appropriate performance measures taken and suggested the development of more comprehensive social CRM performance measures.

Evidently, there is a need for more a comprehensive social CRM performance model. One of the latest attempts toward such a model is proposed by Wittkuhn et al. (2015) and (Küpper et al., 2015). The latter investigated the relationship between four social CRM performance dimensions: infrastructure performance, process performance, customer performance and organizational performance. This approach provides us with deeper insights into social CRM performance within a company. Furthermore, they propose the extension of their social CRM performance model to investigate, for example, the impact of social CRM use on performance outcomes.

Overall, the above-mentioned researchers identified the impact of social CRM adoption on several performance outcomes, usually referring to the dimensions of customer relationship performance (e.g. customer loyalty) and organizational performance (e.g. customer lifetime value). Taking into consideration those two performance dimensions, the following performance outcomes were considered as important by several researchers (Table 5). 
Table 5: Performance outcomes considered as important in previous studies

\begin{tabular}{|c|c|c|}
\hline Performance outcomes & Authors & Description \\
\hline Customer loyalty & $\begin{array}{l}\text { (Greenberg, 2010; Küpper } \\
\text { et al., 2015; Sigala, 2011; } \\
\text { Trainor et al., 2014; } \\
\text { Woodcock et al., 2011) }\end{array}$ & $\begin{array}{l}\text { Development of a strong customer relationship } \\
\text { positively influences customer loyalty. }\end{array}$ \\
\hline New product performance & $\begin{array}{l}\text { (Küpper et al., 2015; } \\
\text { Trainor et al., 2014; } \\
\text { Verhoef et al., 2010; } \\
\text { Woodcock et al., 2011) }\end{array}$ & $\begin{array}{l}\text { The continuous development of new products is } \\
\text { an important source of competitive advantage. The } \\
\text { alignment of new products with customer needs } \\
\text { through company employees who manage customer } \\
\text { relationships is, therefore, crucial. }\end{array}$ \\
\hline Customer lifetime value & $\begin{array}{l}\text { (Küpper et al., 2015; } \\
\text { Verhoef et al., 2010; } \\
\text { Woodcock et al., 2011) }\end{array}$ & $\begin{array}{l}\text { Proper customer engagement can improve net profit } \\
\text { contribution of the customer to the organization over } \\
\text { time. }\end{array}$ \\
\hline Company reputation & $\begin{array}{l}\text { (Küpper et al., 2015; } \\
\text { Sigala, 2011; Woodcock et } \\
\text { al., 2011) }\end{array}$ & $\begin{array}{c}\text { Effectively addressing customer' needs can influence } \\
\text { positive word-of-mouth and improve company } \\
\text { reputation. }\end{array}$ \\
\hline Peer-to-peer communication & $\begin{array}{l}\text { (Greenberg, 2010; Küpper } \\
\text { et al., 2015; Trainor et al., } \\
\text { 2014) }\end{array}$ & $\begin{array}{c}\text { Proper customer encouragement can enhance and } \\
\text { simplify the exchange of information between } \\
\text { customers. }\end{array}$ \\
\hline
\end{tabular}

Researchers are mainly relying on performance outcomes that were already identified in traditional CRM studies. Furthermore, researchers commonly pointed out one performance outcome that is specifically relevant for social CRM: peer-to-peer communication. To conclude, we have noticed the increase of papers that attempt to identify more appropriate performance outcomes for social CRM in the last two years. Nevertheless, the researchers that empirically explored the impact of social CRM on performance outcomes suggest further research in this context.

\section{Conclusion and further research directions}

This study aims to conduct a literature review on social CRM adoption with particular emphasis on factors and performance outcomes based on recently published papers in journals and conferences between 2010 and 2015. We reviewed 31 articles and classified our findings in three categories: the extent of social CRM adoption, the factors influencing social CRM adoption, and the impact of social CRM adoption on performance outcomes. With this categorization, we tried to capture the entire chain of social CRM adoption.
Our observations have confirmed that many researchers proposed social CRM models based on existing theories and concepts of traditional CRM. Those who empirically explored the proposed social CRM models also suggest further adjustments/extensions of their models. Furthermore, despite the increase of publications on social CRM adoption, the analyzed publications are still mainly of a conceptual nature.

Therefore, the systematic and empirical examination of factors that influence social CRM adoption and its implications for performance outcomes is needed. Additionally, more emphasis should be given on how social media extent traditional CRM. Finally, the findings from existing social CRM models should be integrated into a comprehensive social CRM model that will capture the entire chain of social CRM adoption. This will give an overview of the entire social CRM adoption situation.

This literature review on social CRM in the selected period (since 2010) might have been affected by some limitations. First, even though a variety of journals and several renowned conferences in the field of information systems and marketing were considered in this study, it may happen that this topic had also been covered in other journals and conferences. Furthermore, as this study was 
conducted for a limited period, it could be possible that we missed some previous findings regarding this topic as well. Additionally, there might be studies that we missed, because they investigate similar phenomena but discuss it with different terms.

\section{Literature}

Acker, O., Gröne, F., Akkad, F., Pötscher, F., \& Yazbek, R. (2011). Social CRM: How Companies Can Link into the Social Web of Consumers. Journal of Direct, Data and Digital Marketing Practice, 13(1), 3-10. Retrieved from http://papers.ssrn.com/abstract=1899459

Askool, S., \& Nakata, K. (2011). A conceptual model for acceptance of social CRM systems based on a scoping study. AI \& SOCIETY, 26(3), 205-220, http://doi. org/10.1007/s00146-010-0311-5

Askool, S., \& Nakata, K. (2012). Investigation into the adoption intention of social CRM in Saudi banks. In International Conference on Information Society (pp. 402-408). Retrieved from http://www.deepdyve. com/lp/institute-of-electrical-and-electronics-engineers/investigation-into-the-adoption-intention-of-social-crm-in-saudi-banks-etilmNcLca

Awasthi, P., \& Sangle, P. S. (2012). Adoption of CRM technology in multichannel environment: a review (2006 $\square 2010)$. Business Process Management Journal, 18(3), 445-471, http://doi. org/10.1108/14637151211232641

Baird, C. H., \& Parasnis, G. (2011). From social media to Social CRM: reinventing the customer relationship. Strategy \& Leadership, 39(6), 27-34, http://doi. org/10.1108/10878571111176600

Chen, I. J., \& Popovich, K. (2003). Understanding customer relationship management (CRM): People, process and technology. Business Process Management Journal, 9(5), 672-688, http://doi. org/10.1108/14637150310496758

Choudhury, M. M., \& Harrigan, P. (2014). CRM to social CRM: the integration of new technologies into customer relationship management. Journal of Strategic Marketing, 22(2), 149-176, http://doi.or$\mathrm{g} / 10.1080 / 0965254 X .2013 .876069$

Cooper, H. M. (1988). Organizing knowledge syntheses: A taxonomy of literature reviews. Knowledge in Society, 1(1), 104-126, http://doi.org/10.1007/BF03177550

Damanpour, F., \& Schneider, M. (2008). Characteristics of Innovation and Innovation Adoption in Public Organizations: Assessing the Role of Managers. Journal of Public Administration Research and Theory, 19(3), 495-522, http://doi.org/10.1093/jopart/mun021

Faase, R., Helms, R., \& Spruit, M. (2011). Web 2.0 in the CRM domain: defining social CRM. International Journal of Electronic Customer Relationship Management, 5(1), 1, http://doi.org/10.1504/

\section{IJECRM.2011.039797}

Greenberg, P. (2009). CRM at the Speed of Light, Fourth Edition: Social CRM 2.0 Strategies, Tools, and Techniques for Engaging Your Customers: Social CRM 2.0 Strategies, Tools, and Techniques for Engaging Your Customers (4th ed., Vol. 2009). McGraw Hill Professiona. Retrieved from http://books.google.si/books/ about/CRM at the Speed of Light Fourth Edition. html?id=YWOFpc2D c8C\&pgis $=1$

Greenberg, P. (2010). The impact of CRM 2.0 on customer insight. Journal of Business Industrial Marketing, 25(6), 410-419, http://doi.org/10.1108/08858621011066008

Harrigan, P. (2011). Conceptualising social CRM in SMEs. In Australian and New Zealand Marketing Association Conference. Australian and New Zealand Marketing Association Conference. Retrieved from http://eprints. soton.ac.uk/185425/1/ANZMAC_Paper_2011.doc

Harrigan, P., \& Miles, M. (2014). From e-CRM to s-CRM. Critical factors underpinning the Social CRM activities of SMEs. Small Enterprise Research, 21(1), http:// doi.org/10.5172/ser.v21i1.5496

Harrigan, P., Soutar, G., Choudhury, M. M., \& Lowe, M. (2015). Modelling CRM in a social media age. Australasian Marketing Journal (AMJ), 23(1), 27-37, http:// doi.org/10.1016/j.ausmj.2014.11.001

Jayachandran, S., Sharma, S., Kaufman, P., \& Raman, P. (2005). The Role of Relational Information Processes and Technology Use in Customer Relationship Management. Journal of Marketing, 69(4), 177-192, http:// doi.org/10.1509/jmkg.2005.69.4.177

Kietzmann, J. H., Hermkens, K., McCarthy, I. P., \& Silvestre, B. S. (2011). Social media? Get serious! Understanding the functional building blocks of social media. Business Horizons, 54(3), 241-251, http://doi. org/10.1016/j.bushor.2011.01.005

Kiron, D., Palmer, D., Nguyen Phillips, A., \& Berkman, R. (2013). Social Business: Shifting Out of First Gear | MIT Sloan Management Review. Retrieved from http:// sloanreview.mit.edu/reports/shifting-social-business/

Küpper, T., Jung, R., Lehmkuhl, T., Walther, S., \& Wieneke, A. (2014). Performance Measures for Social CRM: A Literature Review. In 27th Bled eConference: eEcosystems (pp. 125-139). Retrieved from https://domino. fov.uni-mb.si/proceedings.nsf/0/400cee09cde2a24ec1257cee0042e351/\$FILE/09_K\%C3\%BCpper_Jung Lehmkuhl_Walther_Wieneke.pdf

Küpper, T., Lehmkuhl, T., Wittkuhn, N., Wieneke, A., \& Jung, R. (2015). Social CRM Performance Model: An Empirical Evaluation. In 28th Bled eConference: \#eWellBeing (pp. 418-435). Retrieved from https:// domino.fov.uni-mb.si/proceedings.nsf/Proceedings/ 2986D15ABF365087C1257E5B004C6396/\$File/4 Kupper.pdf

Leary, B. (2008). Social CRM: Customer Relationship Management in the Age of the Socially-Empowered 
Customer - KnowledgeStorm. Retrieved from http:// www.knowledgestorm.com/sol_summary 5136719. asp

Lehmkuhl, T., \& Jung, R. (2013). Towards Social CRM - Scoping the Concept and Guiding Research. BLED 2013 Proceedings. Retrieved from http://aisel.aisnet. org/bled2013/14

Levy, Y., \& Ellis, T. A systems approach to conduct an effective literature review in support of information systems research, Informing Science: The International Journal of an Emerging Transdiscipline $181-212$ (2006). Retrieved from http://nsuworks.nova.edu/ gscis facarticles/41

Malthouse, E. C., Haenlein, M., Skiera, B., Wege, E., \& Zhang, M. (2013). Managing Customer Relationships in the Social Media Era: Introducing the Social CRM House. Journal of Interactive Marketing, 27(4), 270280, http://doi.org/10.1016/j.intmar.2013.09.008

Michaelidou, N., Siamagka, N. T., \& Christodoulides, G. (2011). Usage, barriers and measurement of social media marketing: An exploratory investigation of small and medium B2B brands. Industrial Marketing Management, 40(7), 1153-1159, http://doi.org/10.1016/j. indmarman.2011.09.009

Paulissen, K., Milis, K., Brengman, M., Fjermestad, J., \& Romano, Jr., N. (2007). Voids in the Current CRM Literature: Academic Literature Review and Classification (2000-2005). In 2007 40th Annual Hawaii International Conference on System Sciences (HICSS'07) (p. 150c-150c). IEEE, http://doi.org/10.1109/ HICSS.2007.609

Piskar, F., \& Faganel, A. (2009). A Successful CRM Implementation Project in a Service Company: Case Study. Organizacija, 42(5), 199-208. Retrieved from http://organizacija.fov.uni-mb.si/index.php/organizacija/article/view/310/620

Reinartz, W., Krafft, M., \& Hoyer, W. D. (2004). The Customer Relationship Management Process: Its Measurement and Impact on Performance. Journal of Marketing Research, 41(3), 293-305, http://doi.org/10.1509/ jmkr.41.3.293.35991

Rodriguez, M., Ajjan, H., \& Peterson, R. M. (2014). CRM/ social media technology: impact on customer orientation process and organizational sales performance. Journal Of Marketing Development and Competitiveness, 8(1), 85-97.

Sarner, A., E., T., Mann, J., Dunne, M., Davies, J., \& Fletcher, C. (2011). Magic Quadrant for Social CRM. Gartner. Retrieved from https://www.gartner.com/ doc/2179417

Sashi, C. M. (2012). Customer engagement, buyer-seller relationships, and social media. Management Decision, 50(2), 253-272, http://doi. org/10.1108/00251741211203551

Sigala, M. (2011). eCRM 2.0 applications and trends:
The use and perceptions of Greek tourism firms of social networks and intelligence. Computers in Human Behavior, 27(2), 655-661, http://doi.org/10.1016/j. chb.2010.03.007

Sussin, J. (2015). Top Use Cases and Benefits of Social for CRM in 2015. Retrieved from http://www.gartner.com/ document/2984019?ref=unauthreader\#

Trainor, K. J. (2012). Relating Social Media Technologies to Performance: A Capabilities-Based Perspective. Journal of Personal Selling and Sales Management, 32(3), 317-331, http://doi.org/10.2753/PSS0885$\underline{3134320303}$

Trainor, K. J., Andzulis, J. (Mick), Rapp, A., \& Agnihotri, R. (2014). Social media technology usage and customer relationship performance: A capabilities-based examination of social CRM. Journal of Business Research, 1201-1208, http://doi.org/10.1016/j.jbusres.2013.05.002

Verhoef, P. C., Reinartz, W. J., \& Krafft, M. (2010). Customer Engagement as a New Perspective in Customer Management. Journal of Service Research, 13(3), 247-252, http://doi.org/10.1177/1094670510375461

Wittkuhn, N. S., Lehmkuhl, T., Küpper, T., \& Jung, R. (2015). Social CRM Performance Dimensions: a Resource-Based view and Dynamic Capabilities Perspective. In 28th Bled eConference: \#eWellBeing (pp. 368-388). Retrieved from https://domino.fov.uni-mb. si/proceedings.nsf/Proceedings/DF0CCA16D41BEB1CC1257E5B004B834D/\$File/1 Wittkuhn.pdf

Woodcock, N., Green, A., \& Starkey, M. (2011). Social CRM as a business strategy. Journal of Database Marketing \& Customer Strategy Management, 18(1), 50-64, http://doi.org/10.1057/dbm.2011.7

Yawised, K., Marshall, P., \& Stockdale, R. (2013). Social CRM: A Review of the Academic and Practitioner Literatures and Research Agendas. In Malaysian Conference on Information Systems (pp. 101-107).

Yawised, K., Marshall, P., \& Stockdale, R. (2013, April 23). Social CRM: A Review of Academic and Practioner Literatures and Research Agendas. Malaysian Conference on Information Systems MCIS2013. Retrieved from http://ecite.utas.edu.au/84151/1/Social CRM_A $\underline{\text { Review of Literature and Research Agendas.pdf }}$ 
Marjeta Marolt is a teaching assistant and a researcher at the Faculty of Organizational Sciences, University of Maribor, Slovenia. Her main research interests include social CRM, e-business and new business models. She was involved in several EU and national projects related to the field of information systems. She obtained her bachelor's degree from University of Maribor in the field of Organizational Information Systems. She is currently a PhD student at the University of Maribor, Faculty of Organizational Sciences.

Andreja Pucihar is an Associate Professor at the Faculty of Organizational Sciences, University of Maribor, Slovenia. She obtained her PhD in the MIS field from the University of Maribor. She is a member of IS department and head of eBusiness Lab. Her recent research is mainly focused to IS innovation, in particular in e-business, business models, social media, living labs and open innovation. She has published over 150 papers in journals and conference proceedings. Since 2004 she has been actively involved into several national, international (EU, CE, cross-border, bilateral) and industry projects. She has been involved in several program commit- tees of international conferences and editorial boards of international journals. Since 2009 she has been serving as a program committee chair of annual international Bled eConference.

Hans-Dieter Zimmermann is a Senior Lecturer at the Institute for Information and Process Management IPM at the FHS St. Gallen, University of Applied Sciences, Switzerland. He has a background in Business Administration and received his doctoral degree in Information Management from the University of St. Gallen (HSG), Switzerland. $\mathrm{He}$ is a Co-Editor in Chief of Electronic Markets - The International Journal on Networked Business. Furthermore, he is an active member of the international scientific community. His major research interests concern changing patterns of communication and interaction arising from the emerging Digital Economy. Especially he is interested in the fields of Electronic Markets and Electronic Business, and in the increasing importance of information and communications technologies in societies. Recently he was involved in research projects addressing open societal innovation and eParticipation. 